CZGS Caizheng guanshui (finance and customs). Subject category of archival holdings in the Number One Historical Archives of Chiria.

GPSYYSA "Gao Pù si yu yushi an" (The case of Gao Pu's illegal private jade sales). Shiliao xunkan (Historical materials trimonthly) nos. 19-28 (Feb. 1930 to March 1931).

GZSL Da Qing lichao Gaozong shilu (Veritable records of the successive reigns of the Qing dynasty-Qianlong reign).

GZZZ Gongzhong dang Qianlong chao zouzhe (Palace memorials of the Qianlong Period). Compiled by the Palace Museum, Documents Section. Taipei: Guoli gugong bowuyuan, 1983.

HJTZ He-ning, ed. Huijiang tongzhi (Comprehensive gazetteer of Altishahr). 1804.

HYXYTZ Fuheng et al., comp. (Qinding) huangyu Xiyu tuzhi (Imperially commissioned gazetteer of the Western Regions of the imperial domain). 1782 .

LFZZ Junjichu lufu zouzhe. Reference copy of palace memorial stored in the Grand Council; a class of document held in the Number One Historical Archives of China.

MZSW Minzu shiwu (Nationality affairs). Subject category of archival holdings in the Number One Historical Archives of China.

NWFLW Neiwufu laiwen (Communications to the Imperial Household Agency). A class of document stored in the Number One Historical Archives of China.

NWYGZY Nayanceng (Na-yan-cheng). Nawen yigong zouyi (Memorials of Nayanceng). Rong'an, ed. 1830.

PDZGEFL Fu-heng, et al., comp. (Qinding) pingding Zhunga'er fanglue (Imperially commissioned military history of the pacification of the Zunghars). 3 vols. (qian, zheng, $x u$ ). 1768.

QDDA Zhongguo diyi lishi dang'an guan (Number One Historical 
Archives of China), ed. "Qianlong chao neidi yu Xinjiang sichou maoyi shiliao" (Materials on silk trade between China proper and Xinjiang in the Qianlong reign). In Qingdai dang'an shiliao congbian 12:44-214. Beijing: Zhonghua Shuju, 1987.

RZSL Da Qing lichao Renzong shilu (Veritable records of the successive reigns of the Qing dynasty-Jiaqing reign).

SYMY Shangye maoyi (Trade and commerce). Subject category of archival holdings in the Number One Historical Archives of China.

SZJL He-ning, ed. Sanzhou jilue (Cursory record of three prefectures: Hami, Turfan, and Urumchi), Preface 1805.

WZSL Da Qing lichao Wenzong shilu (Veritable records of the successive reigns of the Qing dynasty-Xianfeng reign).

XCYL Qi Yunshi, comp. Xichui yaolue (Survey of the Western borders). 1807 .

XJZL Song-yun et al. (Qinding) Xinjiang zhilue (Imperially commissioned gazetteer of Xinjiang), Preface 1821 .

XYWJL Qi-shi-yi (Chunyuan). Xiyu wenjian lu (Record of things heard and seen in the Western Regions). 1777.

XZSL Da Qing lichao Xuanzong shilu. (Veritable records of the successive reigns of the Qing dynasty-Daoguang reign).

YJHL Ge Beng'e. Yijiang huilan (Survey of the Yili River region). 1775 .

YJJZ Yijiang jizai (Record of the Yili River area). C. 1862.

ZPZZ Gongzhong zhupi zouzhe. Rescripted palace memorial; a class of document stored in the Number One Historical Archives of China.

ZTYLSY Yong-bao. Zongtong Yili shivi (Comprehensive survey of affairs in Yili). C. 1795. 


\section{BEYOND THE PASS}


